\title{
Growth and Fruiting Responses of 'Redchief Delicious' Apple Trees to Heading Cuts and Scaffold Limb Removal
}

\author{
Richard P. Marini', John A. Barden', and Donald Sowers \\ Department of Horticulture, Virginia Polytechnic Institute and State University, \\ Blacksburg, VA 24061-0327 \\ Additional index words. Malus domestica, pruning, yield, crop value
}

\begin{abstract}
Three-year-old 'Campbell Redchief Delicious'/MM.111 [Malus domestica (Borkh.)] trees were subjected to a factorial arrangement of annual pruning treatments (removal of excess scaffold limbs vs. no removal, heading the terminal extension shoot on scaffold limbs vs. no heading) plus a treatment involving gradual removal of excess scaffold limbs. Six years after treatments were initiated, pruning treatment did not influence tree height or trunk size. Tree spread was greatest for nonheaded trees. Although yield, yield efficiency, and gross returns were reduced by either type of pruning, there was significant interaction between limb removal and heading. Compared to no limb removal or heading, limb removal plus heading reduced cumulative gross returns by $\approx \$ 12,800 / \mathrm{ha}$.
\end{abstract}

\begin{abstract}
Most apple trees in the mid-Atlantic region of the United States are trained to some variation of a free-standing central leader with a conical tree form. In this training system, the central leader is headed annually to stiffen the leader and induce branching; scaffold limbs are spread to suppress vegetative growth and encourage early fruiting. During the 1970 s, the techniques proposed by Heinicke (197.5) were used widely to develop central leader trees (Dreiling, 1974). This system involves developing scaffold limbs in layers that are spaced vertically, $\approx 60 \mathrm{~cm}$ apart, along the central leader; the first layer contains about five limbs. All 1-year-old wood on young trees is headed by $\approx 25 \%$ to promote terminal and lateral growth and to stiffen the branch. Over the years, this system has been modified to minimize heading terminal shoots on scaffold limbs (Lord and Costante, 1977) and to distribute scaffold limbs evenly along the central leader rather than in layers (Forshey and Elfving, 1976; Stebbins, 1980).

Since spur 'Delicious' limbs develop few side branches (Westwood and Zielinski, 1966), limbs have less fruiting potential than the limbs of nonspur strains. Therefore, to develop more fruiting surface per tree, many commercial apple growers retain all wide-crotched scaffold limbs on spur-type strains.

Results from several experiments indicated that heading terminal extension shoots on scaffold limbs reduced yield on young trees (Elfving, 1990; Elfving and Forshey, 1976; Gardner, 1917; Lord and Damon, 1983; Lord and Sincuk, 1980). Compared to nonpruned trees, removing excess major branches on 3-year-old 'Starking Delicious' trees reduced bloom and yield (Batjer and Westwood, 1963).

Since early fruiting is critical for orchard profitability, it is important to identify the pruning techniques that influence fruiting of young trees. The objective of this study was to evaluate the influence on yield and fruit size of early scaffold limb removal and annual heading of terminal shoots on scaffold limbs. Additionally, we assessed the economic impacts of these pruning practices.
\end{abstract}

Received for publication 8 June 1992. Accepted for publication 23 Nov. 1992. The cost of publishing this paper was defrayed in part by the payment of page charges. Under postal regulations, this paper therefore must be hereby marked advertisement solely to indicate this fact.

'Associate Professor.

${ }^{2}$ Professor.

${ }^{3}$ Research Technician.

\section{Materials and Methods}

In Mar. 1983, 1-year-old whips of 'Campbell Redchief Delicious'/MM.111 were planted at the Virginia Tech Horticultural Research Farm, Blacksburg, Va., at $7.3 \times 5.2-\mathrm{m}$ spacing (264 trees/ ha) and headed at $75 \mathrm{~cm}$. For the first three seasons, all trees were trained uniformly to a central leader form. All scaffold limbs >50 $\mathrm{cm}$ above ground were retained and spread with wooden toothpicks to promote wide crotch angles; scaffold limbs were not headed. Scaffold limbs were spread with $15-\mathrm{cm}$-long wire spreaders in 1985. The extension shoot of the central leader was headed annually to remove $25 \%$ to $30 \%$ of the 1 -year-old wood.

In Mar. 1986, the following five pruning treatments were established on each of 10 trees: 1) all scaffold limbs were retained and none were headed; 2) scaffold heading: all scaffold limbs were retained, and the terminal extension shoot on each scaffold limb was headed annually (1986-91) by removing the terminal onethird of the 1-year-old shoot: 3) scaffold removal: all except four or five scaffold limbs originating within $1.5 \mathrm{~m}$ above ground were removed in 1986, but no scaffold branches were removed thereafter: 4) scaffold removal and heading: all except four or five scaffold limbs were removed in 1986, and the terminal extension shoots were headed annually (198691) by one-third; 5) gradual removal of scaffolds and heading: one or two scaffold limbs per tree were removed annually $1987-89$ so that four or five scaffold limbs were retained after 1989, and terminal extension shoots were headed annually (1986-91) by removing one-third of the 1-yearold wood. All pruning was done annually in March or early April. In all treatments, the extension shoot of the central leader was headed annually by one-third, and all vertical watersprouts and all rootsuckers were removed. Scaffold limbs were reoriented to between $50^{\circ}$ and $65^{\circ}$ from horizontal, with wooden spreaders as needed. Narrow-crotched shoots developing below the terminal extension shoot on the central leader and scaffold limbs were removed annually. Fruits were chemically thinned with carbaryl (1.9 g.liter ${ }^{-1}$ ), and pest control and fertilization practices were according to local recommendations (Pfeiffer, 1991).

Each winter, trunk circumference was measured $15 \mathrm{~cm}$ above

Abbreviations: FW, fruit weight; TCSA, trunk cross-sectional area; YE, yield efficiency. 
Table 1.Growth of 'Campbell Redchief Delicious' apple trees as influenced by removing scaffold branches in 1986 or gradually removing scaffold branches in $1987-89$, and by annual heading of scaffold branches.'

\begin{tabular}{|c|c|c|c|c|c|c|c|c|c|c|c|c|c|}
\hline \multirow{3}{*}{$\begin{array}{l}\text { Treat- } \\
\text { ment } \\
\text { (no.) }\end{array}$} & \multicolumn{2}{|c|}{ Pruning treatment } & & & & & & & & & & & \\
\hline & \multirow{2}{*}{$\begin{array}{l}\text { Annual } \\
\text { heading }\end{array}$} & \multirow{2}{*}{$\begin{array}{l}\text { Scaffold } \\
\text { limb } \\
\text { removal }\end{array}$} & \multicolumn{3}{|c|}{ Tree ht $(\mathrm{cm})$} & \multicolumn{3}{|c|}{ Tree spread $(\mathrm{cm})$} & \multicolumn{5}{|c|}{$\operatorname{TCSA}\left(\mathrm{cm}^{2}\right)$} \\
\hline & & & 1989 & 1990 & 1991 & 1989 & 1990 & 1991 & 1987 & 1988 & 1989 & 1990 & 1991 \\
\hline$\overline{1}$ & No & No & 420 & 466 & 454 & 346 & 358 & 481 & 41 & 55 & 82 & 106 & 120 \\
\hline 2 & Yes & No & 411 & 438 & 445 & 302 & 317 & 436 & 38 & 51 & 75 & 97 & 114 \\
\hline 3 & No & Yes & 433 & 470 & 454 & 336 & 348 & 476 & 42 & 57 & 81 & 106 & 122 \\
\hline 4 & Yes & Yes & 420 & 442 & 455 & 289 & 318 & 464 & 40 & 55 & 81 & 110 & 128 \\
\hline 5 & Yes & Gradual & 422 & 430 & 444 & 300 & 330 & 434 & 40 & 53 & 78 & 104 & 113 \\
\hline \multicolumn{14}{|c|}{ Contrast $(P>F)$} \\
\hline \multicolumn{3}{|c|}{ Heading ( $1+3$ vs. $2+4)$} & 0.80 & 0.98 & 0.36 & 0.89 & 0.56 & 0.11 & 0.53 & 0.26 & 0.38 & 0.28 & 0.28 \\
\hline \multicolumn{3}{|c|}{ Removal $(1+2$ vs. $3+4)$} & 0.16 & 0.75 & 0.44 & 0.32 & 0.62 & 0.24 & 0.38 & 0.67 & 0.55 & 0.20 & 0.14 \\
\hline \multicolumn{3}{|c|}{ Interaction $(1+4$ vs. $2+3)$} & 0.19 & 0.01 & 0.48 & 0.01 & 0.01 & 0.01 & 0.19 & 0.33 & 0.45 & 0.63 & 0.83 \\
\hline \multicolumn{3}{|c|}{ Gradual removal (4 vs. 5 ) } & 0.82 & 0.02 & 0.28 & 0.01 & 0.05 & 0.01 & 0.97 & 0.48 & 0.55 & 0.80 & 0.43 \\
\hline
\end{tabular}

${ }^{2}$ Each mean contains 10 observations, except for 1989 , which contains four observations.

ground. In 1989, 1990, and 1991, tree height and spread (mean of across-row and within-row spread) were recorded. Each year during harvest, at 140 to 150 days after full bloom, fruit were counted and weighed and mean fruit weight (FW) was calculated. In 1988-91, fruit were graded into four sizes with a Durand Wayland (La Grange, Ga.) chain sizer. A sample of 200 fruit per size was collected to calculate mean FW per size, and box counts were calculated as the number of fruit per $19.06-\mathrm{kg}$ unit. Chain sizes of $<69,70$ to 76.77 to 82 , and $>82 \mathrm{~mm}$ had mean FW of $100,138,169$, and $216 \mathrm{~g}$, respectively, and corresponded to box counts of 190, 138,113 , and 88 fruit/box, respectively. Boxes of fruit $(19.07 \mathrm{~kg} /$ box) per size grade per hectare were calculated, and the crop value was estimated using average prices for Virginia 'Delicious' U.S. extra fancy-U.S. fancy combination for 28 Sept. through 28 Nov. 1991.

A randomized complete block design with 10 single-tree replications per treatment was used. The treatment structure was an augmented factorial (Lentner and Bishop, 1986). The factorial component consisted of two heading treatments and two scaffold limbremoval treatments plus a gradual limb removal treatment. All data were subjected to analysis of variance using the GLM procedure of the Statistical Analysis System (Barr et al., 1985). Single degree-of-freedom contrasts were used to test the significance of heading treatments, limb removal treatments, the heading $\mathrm{x}$ limb removal interaction, and limb removal in 1986 vs. gradual limb removal in 1986-89.

\section{Results and Discussion}

Tree height was influenced by pruning treatment only in 1990, when there was an interaction between heading and limb removal (Table I). Trees with headed branches and without branch removal were the shortest, whereas trees with nonheaded branches and with branch removal were the tallest. Tree spread was influenced during 1989-91 by the interaction of heading and scaffold limb removal (Table 1). Trees that were not headed and did not have scaffold limbs removed had the greatest spread, and trees with headed scaffold branches had the smallest spread. Scaffold limb removal in 1986 vs. gradual removal had significant, but inconsistent, effects on tree spread. The weight of fruit at the apical end of 2-year-old wood likely pulled nonheaded limbs down from vertical to more horizontal positions, thereby increasing tree spread. In 2-, 3-, and 4-year-old wood of 'Starkspur Delicious', fruit per spur increased from the basal toward the terminal end of the shoot (Walsh, 1979). Lord and Damon ( 1983) reported that tree spread was reduced by heading, and heading reduced fruiting of the 2-

Table 2. Yield and mean fruit weight of 'Campbell Redchief Delicious' apple trees as influenced by removing scaffold branches in 1986 or gradually removing scaffold branches in 1987-89, and by annual heading of scaffold branches."

\begin{tabular}{|c|c|c|c|c|c|c|c|c|c|c|c|c|c|c|c|c|c|c|c|c|c|}
\hline \multirow{3}{*}{$\begin{array}{l}\text { Treat- } \\
\text { ment } \\
\text { (no.) }\end{array}$} & \multicolumn{2}{|c|}{ Pruning treatment } & & & & & & & & & & & & & \multirow{3}{*}{$\begin{array}{l}\text { Cum. } \\
\text { yield } \\
(\mathrm{kg} / \mathrm{tree})\end{array}$} & \multirow{2}{*}{\multicolumn{6}{|c|}{ Fruit wt $(g)$}} \\
\hline & Annual & $\begin{array}{l}\text { Scaffold } \\
\text { limb }\end{array}$ & \multicolumn{6}{|c|}{ No. fruit/tree } & \multicolumn{6}{|c|}{ Yield (kg/tree) } & & & & & & & \\
\hline & heading & removal & 1986 & 1987 & 1988 & 1989 & 1990 & 1991 & 1986 & 1987 & 1988 & 1989 & 1990 & 1991( & & 1986 & 1987 & 1988 & 1989 & 1990 & 1991 \\
\hline 1 & No & No & $\overline{28}$ & 56 & 248 & 234 & 259 & 997 & 5.3 & 11.0 & 46.7 & 41.9 & 42.8 & 184.0 & 341 & 189 & 198 & 190 & 180 & 161 & 185 \\
\hline 2 & Yes & No & 23 & 32 & 230 & 214 & 210 & 835 & 4.3 & 6.5 & 42.4 & 38.1 & 33.9 & 157.6 & 286 & 187 & 200 & 191 & 178 & 158 & 189 \\
\hline 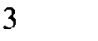 & No & Yes & 29 & 35 & 189 & 176 & 160 & 811 & 5.3 & 7.0 & 36.1 & 32.3 & 29.3 & 156.5 & 278 & 183 & 203 & 194 & 185 & 181 & 193 \\
\hline 4 & Yes & Yes & 18 & 30 & 224 & 128 & 109 & 688 & 3.4 & 6.0 & 42.1 & 24.7 & 19.7 & 136.0 & 248 & 189 & 199 & 189 & 203 & 177 & 198 \\
\hline 5 & Yes & Gradual & 26 & 32 & 185 & 166 & 121 & 730 & 4.8 & 6.4 & 35.2 & 31.3 & 22.3 & 143.8 & 258 & 184 & 202 & 199 & 188 & 181 & 197 \\
\hline \multicolumn{22}{|c|}{ Contrast $(P>F)$} \\
\hline \multicolumn{3}{|c|}{ Heading $(1+3$ vs. $2+4)$} & 0.03 & 0.05 & 0.08 & 0.46 & 0.98 & 0.68 & 0.01 & 0.04 & 0.05 & 0.54 & 0.93 & 0.71 & 0.37 & 0.73 & 0.68 & 0.49 & 0.06 & 0.79 & 0.53 \\
\hline \multicolumn{3}{|c|}{ Removal $(1+2$ vs. $3+4)$} & 0.09 & 0.06 & 0.04 & 0.01 & 0.01 & 0.01 & 0.06 & 0.04 & 0.04 & 0.01 & 0.02 & 0.04 & 0.02 & 0.54 & 0.77 & 0.90 & 0.02 & 0.01 & 0.43 \\
\hline \multicolumn{3}{|c|}{ Interaction $(1+4$ vs. $2+3)$} & 0.01 & 0.04 & 0.59 & 0.07 & 0.14 & 0.02 & 0.02 & 0.01 & 0.75 & 0.08 & 0.08 & 0.04 & 0.01 & 0.18 & 0.26 & 0.61 & 0.06 & 0.10 & 0.18 \\
\hline \multicolumn{3}{|c|}{ Gradual removal (4 vs. 5 ) } & 0.01 & 0.10 & 0.01 & 0.01 & 0.01 & 0.01 & 0.01 & 0.07 & 0.01 & 0.02 & 0.01 & 0.01 & 0.01 & 0.33 & 0.86 & 0.16 & 0.63 & 0.01 & 0.87 \\
\hline
\end{tabular}

${ }^{2}$ Each mean contains 10 observations, except for 1989 , which contains four observations. 
Table 3. Yield efficiency (YE) and fruit size distribution of 'Campbell Redchief Delicious' apple trees as influenced by removing scaffold branches in 1986 or gradually removing scaffold branches in $1987-89$, and by annual heading of scaffold branches.

\begin{tabular}{|c|c|c|c|c|c|c|c|c|c|c|c|c|}
\hline \multirow{3}{*}{$\begin{array}{l}\text { Treatment } \\
\text { (no.) }\end{array}$} & \multicolumn{2}{|c|}{ Pruning treatment } & & & & & & \multirow{3}{*}{$\begin{array}{c}\text { Cumulative YE } \\
1988-91\end{array}$} & \multirow{2}{*}{\multicolumn{4}{|c|}{$\begin{array}{c}\text { Fruit/box" } \\
\text { in given class }(\%) \\
1988-91\end{array}$}} \\
\hline & Annual & $\begin{array}{l}\text { Scaffold } \\
\text { limb }\end{array}$ & \multicolumn{5}{|c|}{$\mathrm{YE}\left(\mathrm{kg} \cdot \mathrm{cm}^{-2} \mathrm{TCSA}\right)^{y}$} & & & & & \\
\hline & heading & removal & 1987 & 1988 & 1989 & 1990 & 1991 & & 190 & 138 & 113 & 88 \\
\hline 1 & No & No & 0.28 & 0.88 & 0.51 & 0.45 & 1.53 & 2.40 & 3.5 & 15.2 & 35.4 & 45.8 \\
\hline 2 & Yes & No & 0.17 & 0.82 & 0.53 & 0.38 & 1.38 & 2.07 & 3.6 & 15.2 & 35.9 & 45.4 \\
\hline 3 & No & Yes & 0.17 & 0.64 & 0.41 & 0.27 & 1.28 & 1.94 & 1.9 & 11.0 & 32.3 & 54.7 \\
\hline 4 & Yes & Yes & 0.15 & 0.78 & 0.30 & 0.17 & 1.06 & 1.64 & 1.7 & 9.7 & 30.1 & 58.6 \\
\hline 5 & Yes & Gradual & 0.15 & 0.67 & 0.41 & 0.21 & 1.27 & 1.94 & 1.7 & 10.3 & 30.4 & 57.5 \\
\hline \multicolumn{13}{|c|}{ Contrast $(P>F)$} \\
\hline \multicolumn{3}{|c|}{ Heading $(1+3$ vs. $2+4)$} & 0.03 & 0.06 & 0.08 & 0.88 & 0.60 & 0.93 & 0.70 & 0.50 & 0.37 & 0.36 \\
\hline \multicolumn{3}{|c|}{ Removal $(1+2$ vs. $3+4)$} & 0.01 & 0.01 & 0.01 & 0.01 & 0.01 & 0.01 & 0.01 & 0.01 & 0.01 & 0.01 \\
\hline \multicolumn{3}{|c|}{ Interaction $(1+4$ vs. $2+3)$} & 0.02 & 0.34 & 0.25 & 0.18 & 0.01 & 0.34 & 0.80 & 0.46 & 0.54 & 0.46 \\
\hline \multicolumn{3}{|c|}{ Gradual (4 vs. 5) } & 0.199 & 0.01 & 0.05 & 0.01 & 0.01 & 0.05 & 0.09 & 0.01 & 0.02 & 0.01 \\
\hline
\end{tabular}

Each mean contains 40 observations. Fruit per box: $190,138,113$, and 88 correspond to fruit diameters of 62 to $69 \mathrm{~mm}, 70$ to $76 \mathrm{~mm}, 77$ to $82 \mathrm{~mm}$, and $>82 \mathrm{~mm}$, respectively.

yEach mean contains 10 observations, except 1989, which contains four observations.

year-old wood, particularly at the terminal end of 'Redspur Delicious' trees. Throughout our experiment, TCSA was independent of pruning treatment (Table 1). TCSA increment of 'Empire' trees declined linearly with increasing heading severity the year of heading, but not the year after heading (Elfving, 1990). In other studies, removing excess limbs (Batjer and Westwood, 1963) and heading scaffold limbs (Lord and Damon, 1983) had little influence on TCSA increment. Although nonpruned trees appeared to possess more than the desired number of scaffold limbs in the lower part of the tree, we observed no adverse effects on branch growth or central leader development.

For the first 3 years of this experiment, the number of fruit per tree and yield were reduced by heading, and limb removal reduced yield throughout the experiment (Table 2). In all years except 1988, yield was influenced by the interaction of heading $\mathrm{x}$ limb removal. Compared to no heading or limb removal, cumulative yields were reduced $15 \%$ by heading, $18 \%$ by limb removal, and $27 \%$ by heading plus limb removal (Table 2). Removing limbs gradually reduced yield less than removing all excess limbs in 1986. Compared to nonpruned trees, trees with excessive limbs removed on 3-year-old 'Delicious' trees had $42 \%$ less yield for the
3 years following treatment (Batjer and Westwood, 1963). Compared to nonheaded trees, cumulative yield was reduced $25 \%$ and $77 \%$, respectively, by heading 1-year-shoots on 7-year-old 'Redspur Delicious' (Lord and Damon, 1983) and 5-year-old 'Spartan' trees (Lord and Sincuk, 1980). When terminal extension shoots on scaffold limbs of 2-year-old 'Empire' trees were headed, Elfving (1990) reported a negative linear relationship between heading severity and cumulative yield for the subsequent 4 years. Heading likely reduced yield by reducing spur count due to bud removal by pruning and stimulation of growing points to develop into shoots rather than spurs (Elfving, 1990; Elfving and Forshey, 1976).

FW was highest during 1989 and 1990 for trees with limbs removed (Table 2). probably because these trees had fewer fruit per tree. Similar results were reported for 'Starking Delicious' trees following removal of excess limbs (Batjer and Westwood, 1963). Heading influenced FW only in 1989, when FW was higher on headed than nonheaded trees $(P=0.06)$

Yield efficiency (YE; $\mathrm{kg} / \mathrm{cm}^{2}$ TCSA) was reduced by heading in 1987 and 1988, whereas YE was reduced throughout the experiment by limb removal (Table 3). In general, treatments that reduced yield also reduced YE, because TCSA was not affected by

Table 4. Cumulative fruit packout and crop value (1988-91) of 'Campbell Redchief Delicious' apple trees as influenced by removing scaffold branches in 1986 or gradually removing scaffold branches in 1987-89. and by annual heading of scaffold branches.

\begin{tabular}{|c|c|c|c|c|c|c|c|c|}
\hline \multirow{3}{*}{$\begin{array}{l}\text { Treat- } \\
\text { ment } \\
\text { (no.) }\end{array}$} & \multicolumn{2}{|c|}{ Pruning treatment } & \multirow{2}{*}{\multicolumn{5}{|c|}{$\frac{\text { Fruit/box }}{\text { Cumulative yield (boxes/ha) }}$}} & \multirow{3}{*}{$\begin{array}{c}\text { Estimated cum. } \\
\text { gross return }(1988-91) \\
(\$ / \mathrm{ha} \times 1000)^{y}\end{array}$} \\
\hline & \multirow{2}{*}{$\begin{array}{l}\text { Annual } \\
\text { heading }\end{array}$} & \multirow{2}{*}{$\begin{array}{l}\text { Scaffold limb } \\
\text { removal }\end{array}$} & & & & & & \\
\hline & & & 190 & 138 & 113 & 88 & Total & \\
\hline 1 & No & No & 93 & 586 & $14 \overline{78}$ & 2556 & 4725 & 49.6 \\
\hline 2 & Yes & No & 74 & 436 & 1246 & 2207 & 3960 & 40.5 \\
\hline 3 & No & Yes & 42 & 301 & 1051 & 2466 & 3854 & 41.1 \\
\hline 4 & Yes & Yes & 29 & 216 & 808 & 2387 & 3432 & 36.8 \\
\hline 5 & Yes & Gradual & 34 & 235 & 840 & 2463 & 3564 & 38.3 \\
\hline \multicolumn{9}{|c|}{ Contrast $(P>F)$} \\
\hline \multicolumn{3}{|c|}{ Heading $(1+3$ vs. $2+4)$} & 0.76 & 0.37 & 0.88 & 0.31 & 0.37 & 0.37 \\
\hline \multicolumn{3}{|c|}{ Removal $(1+2$ vs. $3+4)$} & 0.01 & 0.01 & 0.01 & 0.66 & 0.02 & 0.02 \\
\hline \multicolumn{3}{|c|}{ Interaction $(1+4$ vs. $2+3)$} & 0.15 & 0.01 & 0.01 & 0.14 & 0.01 & 0.02 \\
\hline \multicolumn{3}{|c|}{ Gradual (4 vs. 5 ) } & 0.01 & 0.01 & 0.01 & 0.67 & 0.01 & 0.01 \\
\hline
\end{tabular}

Number of fruit/box; box $=19.06 \mathrm{~kg} ; 190$ fruit/box $=$ Bags. Each value is the mean of 10 observations.

y Price per box was: $190=\$ 9,138=\$ 11,113=\$ 12$, and $88=\$ 13$. 
pruning treatments. Compared to nonpruned trees, heading, limb removal, and heading plus limb removal reduced YE 14\%, 19\%. and $31 \%$, respectively. Heading also reduced $\mathrm{YE}$ in previous studies (Elfving, 1990; Lord and Damon, 1983).

Heading did not influence fruit size distribution (Table 3). Limb removal increased the proportion of fruit in the largest size. Limb removal reduced the number of boxes of fruit per hectare in all but the largest size (box count 88; Table 4). Cumulative yield (boxes per hectare) and cumulative gross returns per hectare were significantly ( $P £ 0.02$ ) influenced by the interaction of limb removal $\mathrm{x}$ heading. Compared to no pruning, limb heading plus removal reduced cumulative yield and gross returns by $26 \%$ and $27 \%$, respectively. Cumulative gross returns were reduced by $14 \%$ and $9 \%$ by the main effect of limb removal and limb heading, respectively. Compared to gradual limb removal, limb removal in 1986 reduced returns by $4 \%$. Although we did not record pruning time, the heading treatment required » $3 \mathrm{~min} /$ tree in 1986 and increased to » $10 \mathrm{~min} /$ tree in 1991. If pruning costs were accounted for, all pruning treatments would likely have reduced returns to a greater extent than indicated in Table 4.

Our results indicate that removal of scaffold limbs and annually heading 1-year-old wood can have a long-term negative effect on productivity and orchard profitability. Our results confirm previous suggestions (Elfving, 1990; Gardner, 1917; Lord and Damon, 1983) that pruning young trees should be minimized and, when possible, heading should be avoided.

\section{Literature Cited}

Barr, A.J., J.H. Goodnight, J.P. Sall, and J.T. Helwig. 1985. SAS user's guide: Statistics version. 5th ed. SAS Institute, Cary, N.C.

Batjer, L.P. and M.N. Westwood. 1963. Effects of pruning, nitrogen, and scoring on growth and bearing characteristics of young Delicious apple trees. Proc. Amer. Soc. Hort. Sci. 82:5-10.
Dreiling, F.R. 1974. Training and pruning apple trees, p. 17-22. In: J.A. Barden, R.E. Byers, F.R. Dreiling, G.D. Oberle, G.E. Mattus, E.L. Phillips, and G.R. Williams. Production management practices for apples, peaches, and nectarines. Va. Polytechnic Inst. State Univ. Coop. Ext. Publ. 595.

Elfving, D.C. 1990. Growth and productivity of 'Empire' apple trees following a single heading-back pruning treatment. HortScience 25:908910.

Elfving, D.C. and C.G. Forshey. 1976. Growth and fruiting responses of vigorous apple branches to pruning and branch orientation treatments. J. Amer. Soc. Hort. Sci. 101:290-293.

Forshey, C.G. and D.C. Elfving. 1976. Training and pruning apple trees. N.Y. Ext. Info. Bul. 112.

Gardner, V.R. 1917. The winter heading-back and thinning-out of apple shoots in young trees. Ore. Agr. Expt. Sta. Bul. 146:57-78.

Heinicke, D.R. 1975. High-density apple orchards-planting, training, and pruning. U.S. Dept. Agr. Hdbk 458.

Lentner, M. and T. Bishop. 1986. Experimental design and analysis. Valley Book Co., Blacksburg, Va.

Lord, W.J. and J. Costante. 1977. Establishment and management of compact apple trees: Part 3. Mass. Agr. Ext. Serv. Fruit Notes 42(2):15-28.

Lord, W.J. and R.A. Damon, Jr. 1983. Growth and fruiting responses of 'Redspur Delicious' apple trees to pruning treatments. J. Amer. Soc. Hort. Sci. 108:867-871.

Lord, W.J. and J. Sincuk. 1980. Progress report: Pruning effects on tree growth and fruiting of Spartan apple. Mass. Agr. Ext. Serv. Fruit Notes 45(5):1-8.

Pfeiffer, D.G. 1991. 1991 spray bulletin for commercial tree fruit growers. Va. Coop. Ext. Publ. 456-419.

Stebbins, R.L. 1980. Training and pruning apple and pear trees. Pacific NW Ext. Publ. 156.

Walsh, C.S. 1979. The effects of node position, shoot vigor, and strain on 'Delicious' apple spur development. J. Amer. Soc. Hort. Sci. 104:825$\mathrm{x} 2 \mathrm{x}$.

Westwood, M.N. and Q.B. Zielinski. 1966. Comparative growth habit and leaf composition of a compact mutant and standard Delicious apple. Proc. Amer. Soc. Hort. Sci. 88:9-13. 